\title{
KARBON PADA PADANG LAMUN DI PERAIRAN PULAU MANADO TUA
}

\author{
(Carbon in seagrass beds in old Manado island waters)
}

\author{
Mikhael A. Maramis ${ }^{1}$, Billy Th. Wagey ${ }^{1 *}$, Antonius P Rumengan ${ }^{1}$, Calvyn F.A. Sondakh ${ }^{1}$, Esry T. \\ Opa ${ }^{1}$, Khristin F.I Kondoy ${ }^{2}$
}

1)Program Studi IImu Kelautan, FPIK, Universitas Sam Ratulangi, Manado.

2)Program Studi Manajemen Sumberdaya Perairan, FPIK, Universitas Sam Ratulangi, Manado.

Corresponding author: billywagey@unsrat.ac.id

\begin{abstract}
Increased greenhouse gas (GHG) emissions, including carbon dioxide $\left(\mathrm{CO}_{2}\right)$ which occurs continuously resulting in global warming and climate change that have an impact on weather patterns and affect life on earth. Seagrass ecosystems are known to have the ability to absorb carbon dioxide and store it for a long time. Research has been conducted to determine the diversity of seagrass species, cover presentation and carbon content in seagrass beds in the waters of Manado Tua Island. To determine species diversity, direct observations were made at each research station and to determine the percentage of seagrass cover using the quadrant line transect method by adopting Seagrass Watch where seagrass samples were also obtained from the quadrant line transect at the whole station then analyzed later using the Loss on ignition (LOI) method. The results of this study were obtained on all stations of the $\mathrm{H}$ ' 1 diversity index medium category with closing percentage and condition status at state stations $36 \%$ less rich / less healthy, Pangalingan station $69 \%$ rich / healthy, Papindang station $51 \%$ less rich / less healthy: carbon content obtained at the all stations were $222.85 \mathrm{gC}$

Keywords: Seagrass Diversity, Closure Percentage, Carbon Content, Quadrant Transect Line, LOI (Loss On Ignition), Manado Island.

Peningkatan emisi gas rumah kaca (GRK) antara lain karbondioksida $\left(\mathrm{CO}_{2}\right)$ yang terjadi terus menerus mengakibatkan terjadinya pemanasan global dan perubahan iklim yang berdampak pada pola cuaca dan mempengaruhi kehidupan di bumi. Ekosistem padang lamun diketahui memiliki kemampun dalam menyerap karbondioksida dan menyimpannya dalam waktu yang lama. Telah dilakukan penelitian untuk mengetahui keanekaragaman jenis lamun, presentasi tutupan dan kandungan karbon pada padang lamun di perairan Pulau Manado Tua. Untuk mengetahui keanekaragaman jenis dilakukan pengamatan secara langsung pada setiap stasiun penelitian dan untuk mengetahui presentase tutupan lamun menggunakan metode line transek kuadran dengan mengadopsi Seagrass Watch dimana sampel lamun juga diperoleh dari line transek kuadran pada keseluruhan stasiun kemudian dianalisis selanjutnya menggunakan metode Loss on ignition (LOI). Didapatkan hasil penelitian pada keseluruhan stasiun indeks keanekaragaman H' 1 kategori sedang dengan presentase penutupan dan status kondisi pada stasiun negri $36 \%$ kurang kaya/kurang sehat, stasiun pangalingan $69 \%$ kaya/sehat, stasiun papindang $51 \%$ kurang kaya/kurang sehat : kandungan karbon pada keseluruhan stasiun yang didapat sebesar $222,85 \mathrm{gC}$
\end{abstract}

\footnotetext{
Kata Kunci : Keanekaragaman Lamun, Presentase Penutupan, Kandungan Karbon, Line Transek, Kuadran, LOI (Loss On Ignition), Pulau Manado Tua.
} 


\section{PENDAHULUAN}

Indonesia merupakan negara kepulauan terbesar di dunia yang terdiri dari 16.344 pulau besar dan kecil dengan panjang garis pantai $81.000 \mathrm{~km}$ yang kayaakan keanekaragaman hayati memiliki ekosistem laut yang sangat khas seperti terumbu karang hutan mangrove dan padang lamun. (Nurul, et al. 2018). Luasan lamun di Indonesia yang telah dihitung sebesar 150.693,16 ha. dengan kondisi kurang sehat dikategorikan dalam Keputusan Menteri Lingkungan Hidup nomor 200 Tahun 2004 (Udhi, et al. 2017).

Menurut (Wagey 2013), hamparan vegetasi lamun yang menutupi suatu area pesisir laut dangkal, terbentuk dari satu jenis atau lebih dengan kerapatan padat atau jarang ekologi padang lamun yang terdiri dari komponen biotik dan abiotik yang disebut ekosistem padang lamun

Lamun memiliki fungsi dan peran sebagai habitat biota, stabilisator dasar perairan, penahan gelombang, pengikat karbon dioksida dan penyimpan karbon.

Peningkatan emisi gas rumah kaca (GRK) antara lain karbondioksida $\left(\mathrm{CO}_{2}\right)$ secara terus menerus di atmosfer mengakibatkan terjadinya pemanasan global dan perubahan iklim yang berdampak pada pola cuaca dan mempengaruhi kehidupan di bumi (Nellemann, et al. 2009). Padang lamun diketahui memiliki kemampuan untuk mengurangi karbondioksida $\left(\mathrm{CO}_{2}\right)$ lebih baik dari vegetasi yang ada di daratan (Mcleod, et al. 2011)

Menurut Kawaroe (2009) lamun mengambil karbon dioksida dari atmosfer dalam prosesnya yang dikenal sebagai "fotosintesis". Fotosintesis adalah proses penyusunan dari zat organik $\mathrm{H}_{2} \mathrm{O}$ dan $\mathrm{CO}_{2}$ menjadi senyawa organik.

Ekosistem lamun dapat menyimpan sebanyak 83.000 metrik ton karbon dalam setiap kilometer persegi dan menyimpanyan dalam jaringan bagian lamun atau sedimen dalam waktu yang cukup lama (Fourqurean, et al. 2012) keberadaan lamun di bumi sangat diperluhkan karena dapat berperan sebagai reservoir karbon di lautan (carbon sink) atau dikenal dengan istilah karbon biru (blue carbon) (Kennedy dan Bjork, 2009).

Menurut Wagey (2018), masih sedikit laporan tentang simpanan karbon padang lamun di Indonesia, khususnya di Sulawesi Utara.

Penelitian ini dilakukan di perairan Pulau Manado Tua Kecamatan Bunaken Timur Provinsi Sulawesi Utara dengan tujuan penelitan; mengetahui keanekaragaman jenis lamun, menentukan presentase tutupan padang lamun dan menghitung simpanan karbon padang lamun di Perairan Pulau Manado Tua menggunakan metode loss on ignition (LOI). 


\section{METODE PENELITIAN}

Tepat dan Waktu Penelitian

Penelitian dilaksanakan selama 6 bulan (Juli 2019 -Januari 2020). Sampel dan data lamun didapat dari Perairan Pulau Manado Tua dengan tiga lokasi yaitu 1.

Selanjutnya analisis sampel dilaksanakan di Laboratorium Terpadu Universitas Sam Ratulangi Manado.
Desa Negri, 2. Desa Pangalingan dan 3. Desa Papindang Kecamatan Bunaken Timur Provinsi Sulawesi Utara. Lokasi pengambilan data dan sampel dapat di lihat pada gambar 1 .

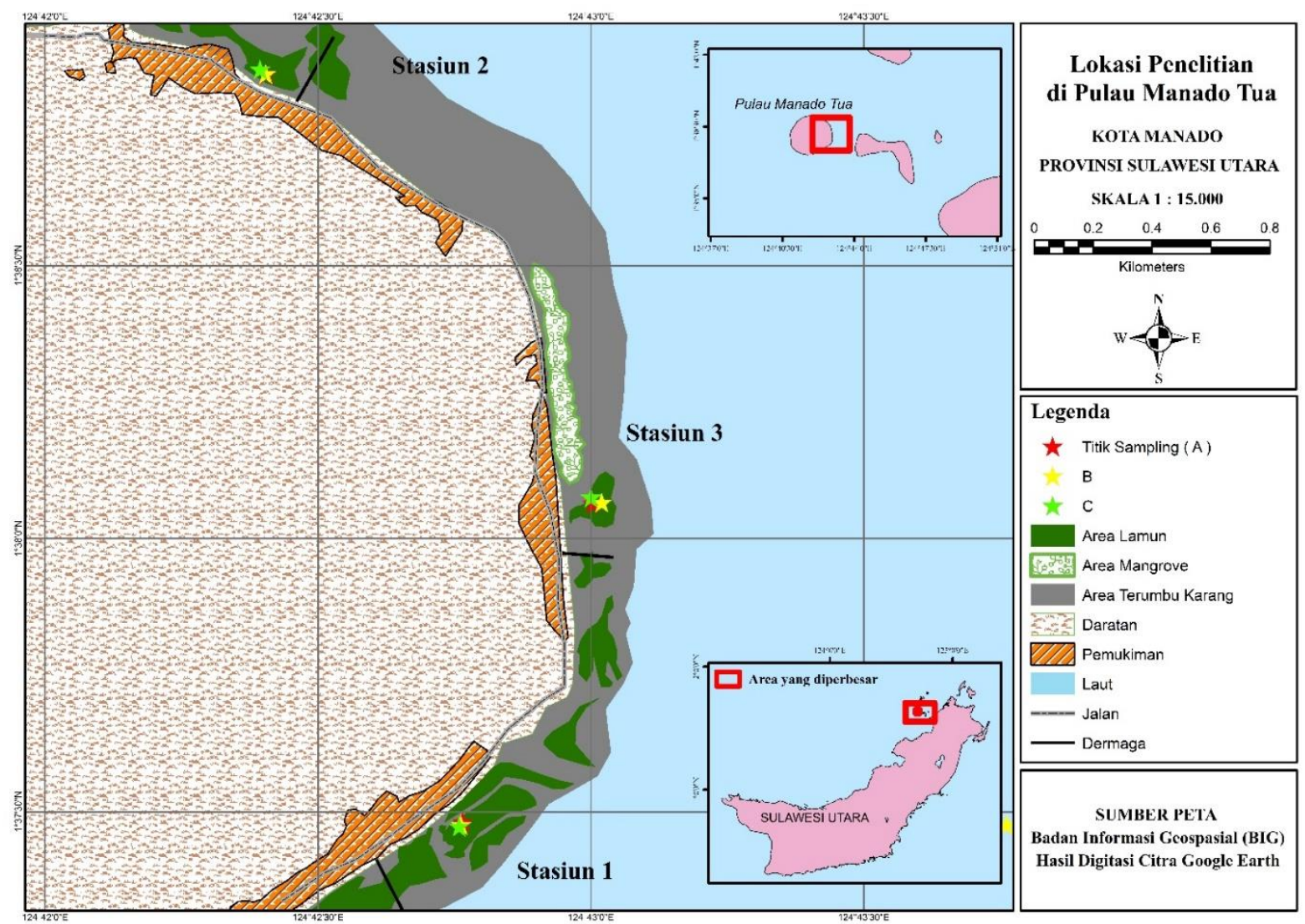

Gambar 1. Lokasi Pengambilan Data dan Sampel

\section{Alat dan Bahan}

Kegiatan penelitian ini dikerjakan baik di lapangan maupun di ruang kerja Laboratorium dengan menggunakan sejumlah peralatan dan bahan seperti dicantumkan dalam tabel 1. 
Tabel 1. Alat untuk pengambilan data dan sampel

\begin{tabular}{|c|c|}
\hline Alat & Kegunaan \\
\hline Skop & $\begin{array}{l}\text { Alat untuk mengambil sampel lamun yang berbentuk seperti tabung } \\
\text { panjang untuk mendapatkan sampel Lamun pada kedalaman tertentu. }\end{array}$ \\
\hline Perahu & Untuk memudahkan transportasi ke lokasi pengambilan sampel. \\
\hline $\begin{array}{l}\text { Kuadran }(50 \times 50 \\
\left.\mathrm{cm}^{2}\right)\end{array}$ & $\begin{array}{l}\text { Berfungsi untuk menghitung persentasi tutupan lamun dan pengambilan } \\
\text { sampel lamun }\end{array}$ \\
\hline Kantong sampel & Untuk menyimpan sampel sebelum di analisi di laboratorium. \\
\hline Alat senorkeling & $\begin{array}{l}\text { Memudahkan visualisasi dan pernapasan dalam air dan pengambilan } \\
\text { sampel jika air pasang }\end{array}$ \\
\hline Cool box sampel & Tempat penyimpanan sampel \\
\hline $\begin{array}{l}\text { GPS (Global } \\
\text { Positoning seystem) } \\
\text { Garmin Etrex } 10\end{array}$ & Untuk menentukan titik lokasi pengambilan data. \\
\hline Meteran & Untuk mengukur jarak line transek \\
\hline $\begin{array}{l}\text { Kamera underwater/ } \\
\text { kamera tahan air }\end{array}$ & Untuk dokumentasi kegiatan selama di lokasi. \\
\hline Kertas label & Untuk memberikan tanda keterangan sampel yang diambil. \\
\hline $\begin{array}{l}\text { Drybag (Tas anti } \\
\text { air) }\end{array}$ & Tempat menaru alat tulis menulis dan sampel \\
\hline Alat tulis & $\begin{array}{l}\text { Untuk mencatat hal-hal penting terkait dengan pengambilan sampel di } \\
\text { lokasi. }\end{array}$ \\
\hline
\end{tabular}

Tabel 2. Alat dan bahan yang digunakan di laboratorium

\begin{tabular}{|c|c|}
\hline Alat dan Bahan & Kegunaan \\
\hline Alumunium foil & $\begin{array}{l}\text { Di jadikan wadah untuk mengeringkan sampel pada saat di jemur, } \\
\text { sebelum dibakar dalam muffle furnace }\end{array}$ \\
\hline Sampel Lamun & Objek yang diteliti \\
\hline Timbangan Analitik & $\begin{array}{l}\text { Untuk menimbang sampel sedimen dengan ketelitian tinggi ( } 4 \text { angka } \\
\text { dibelakang koma) }\end{array}$ \\
\hline Timbangan digital & $\begin{array}{l}\text { Untuk menimbang sampel sedimen dengan ketelitian sedang ( } 2-3 \\
\text { angka dibelakang koma) }\end{array}$ \\
\hline Desikator & Untuk mendinginkan Sampel setelah dikeluarkan dari dalam tanur \\
\hline Silika & Untuk melumaskan penutup desikator \\
\hline $\begin{array}{l}\text { Cawan Sampel (Crucible } \\
\text { porcelain) }\end{array}$ & $\begin{array}{l}\text { Sebagai wadah untuk menempatkan sampel selama pengeringan di } \\
\text { dalam oven }\end{array}$ \\
\hline Blender & Untuk menghaluskan sampel \\
\hline Crucible porcelain & $\begin{array}{l}\text { Untuk menempatkan sampel (setelah ditimbang } 3 \text { gram) selama } \\
\text { pembakaran sampel dalam muffle furnace }\end{array}$ \\
\hline Muffle Furnace & Untuk membakar sampel (pengabuan) \\
\hline
\end{tabular}




\section{Pengambian dan Penanganan Sampel di Lokasi}

\section{Pengambilan Data dan Sampel}

Data dan sampel lamun diperoleh dari 1. Desa Negri, 2. Desa Pangalingan dan 3. Desa Papindang pada Pulau Manado Tua Kecamatan Bunaken Timur. Metode yang digunakan dalam melihat keanekaragaman dan prensentase tutupan lamun adalah line transek kuadran dengan mengadopsi Seagrass Watch (Hutomo dan Nonji, 2014) yaitu dengan menggunakan kuadran yang dibuat dari pipa paralon (PVC ukuran 1/2) $50 \times 50 \mathrm{~cm}$ yang telah di bagi menjadi 4 ruang yang berukuran $25 \mathrm{x}$ $25 \mathrm{~cm}$ pengamatan dilakukan secara visual menurut panduan persentase tutupan lamun standar Seagrass Watch (McKenzie, et al. 2003). Penentuan titik pengambilan sampel dilakukan dengan menarik meter pada saat air surut dengan kedalaman antara 0-70 cm sepanjang 50 meter tegak lurus dari garis pantai atau dari arah darat ke laut, kemudian kuadran diletakkan dari titik 0 meter disebelah kanan dengan masing-masing jarak 10 meter dengan pengulangan pada setiap lokasi sebanyak 3 kali pengulagan, skema line trasnsek kuadran dapat dilihat pada gambar 2.

Sampel lamun diambil dari setiap kuadran yang telah dilakukan pengamatan kenaekaragaman dan presentase tutupan lamun, pada setiap stasiun diperoleh 18 sampel sehingga total keseluruhan sampel dari semua lokasi adalah 54 sampel.

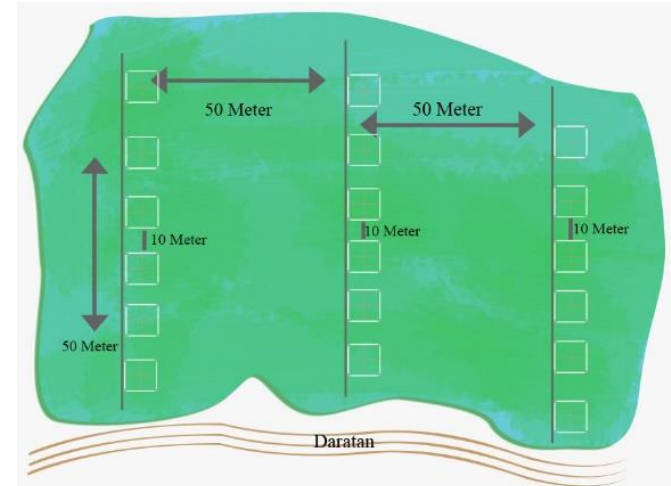

Gambar 2. Skema line transek kuadran pada setiap stasiun

\section{Penanganan Sampel}

Tahapan yang dilakukan untuk pengambilan dan penanganan sampel lamun yang kemudian dianalisi untuk mengetahui kandungan karbon adalah sebagai berikut:

a) Pengambilan sampel dilakukan pada line transek kuadran yang telah dilakukan pengamatan keanekaragaman dan presentase tutupan lamun pada setiap stasiun

b) Sampel lamun diambil menggunakan alat skop dimana lamun dicabut utuh sampai dengan rhizoma dan akarnya

c) Setelah sampel diperoleh, samper dibersihkan atau dipisahkan dari pasir dan lumpur yang menempel pada akar lamun dan dimasukan kedalam plastik sampel sesuai lebel yang sudah diberikan, sampel yang sudah diberikan lebel dimasukan kedalam cool box yang sudah diisi dengan es batu agar bertahan sampai pada saatnya di analisis di laboratorium 


\section{Analisis Sampel dan Pengolahan Data}

\section{Analisis Sampel di Laboratorium}

Setelah pengambilan sampel di lokasi selesai, kemudian sampel yang diperoleh dianalisis di laboratorium dengan metode loss on ignition (LOI) metode ini pada prinsipnya adalah menghilangkan bahan organik melalui proses pembakaran di dalam tanur/tungku (furnace). Nilai bahan organik yang didapat merupakan berat sampel yang hilang karena pembakaran pada suhu tertentu 450550드 selama 4-8 jam (Heiri, et al. 2001; Santisteban, et al. 2004; Fourqurean, et al. 2014).

Tahapannya sebagai berikut:

a) Sebelum sampel lamun di gerus dan dimasukan kedalam tanur sampel akan dikeringkan terlebih dahulu dengan menimbang (A) berat basah sebelum sampel di keringkan dan (B) berat konstan setelah sampel dikeringkan, sampel dikeringkan dengan cara di jemur pada terik matahari selama 3 hari

b) Setelah sampel kering sampel dihomogenasi dengan cara dihaluskan pada mesin blender sampai halus dengan ukuran partikel menjadi sama

c) Sampel yang telah dikeringkan dan dihomogenasi ditimbang sebanyak 3 gram dan dimasukan kedalam cawan porselen yang sudah ditimbang terlebih dahulu d) Sampel dalam cawan porselen kemudian dimasukkan kedalam tanur untuk dibakar pada suhu $500^{\circ} \mathrm{C}$ selama 4 jam

e) Sesudah sampel dibakar selama 4 jam sampel didinginkan selama 10 menit didalam desikator, kemudain ditimbang dan dicatat hasilnya

f) Dihitung menggunakan rumus pada persamaan 3;

\section{Pengolahan Data}

Data yang dihitung adalah keanekaragaman, presentase tutupan, kandungan bahan organik dan kandungan karbon. Adapun perhitungan yang digunakan dalam menganalisis data sebagai berikut:

1. Indeks keanekaragaman

digunakan untuk mengukur kelimpahan komunitas berdasarkan jumlah jenis spesies dan jumlah individu dari setiap spesies rumus yang digunakan untuk menghitung indeks keanekaragaman lamun adalah shanon-wiener (Fachrul, 2007) disajikan pada persamaan 1 :

$$
H^{\prime}=-\sum_{i=1}^{s}(n i / N \ln n i / N)
$$

Keterangan:

$\mathrm{H}^{\prime} \quad$ = Indesk keanekaragaman spesies

$\mathrm{Ni}=$ Jumlah individu dalam spesies ke i

$\mathrm{N}=$ Jumlah total individu

Kriteria indek keanekaragaman menurut Shannon- Wiener didefinisikan sebagai berikut

$H^{\prime}<1$ Keanekaragaman spesies rendah 
Jurnal Pesisir dan Laut Tropis

$1<\mathrm{H}^{\prime}<3$ Keanekaragaman spesies sedang $\mathrm{H}>3$ Keanekaragaman spesies tinggi

2. Untuk menghitung penutupan lamun dalam satu kuadran adalah dengan menjumlah nilai penutupan lamun pada setiap kotak kecil dan membaginya dengan jumlah kotak kecil (Hutomo and Nonji, 2014). Penutupan lamun dihitung menggunakan persamaan 2 .

Pentupan Lamun(\%) $=\frac{\text { jumlah tutupan lamun } 4 \text { kotak }}{\text { jumlah kotak }(4)}$

Sedangkan untuk menentukan nilai rata-rata penutupan lamun per stasiun adalah hasil dari penutupan lamun pada seluruh transek kemudian dibagi dalam jumlah kuadran seluruh transek (Hutomo and Nonji, 2014). Untuk menghitung nilai rata-rata penutupan lamun menggunakan persamaan 3 .

Rata - rata penutupa $(\%)=\frac{\text { jumlah penutupan lamun seluruh transek }}{\text { jumlah kuadran seluruh transek }}$

Kemudian untuk menentukan suatu kondisi padang lamun dapat dihitung berdasarkan Keputusan Mentri Lingkungan Hidup no 200 tahun 2004 tentang Kriteria Baku Kerusakan Penutupan Status Padang Lamun yaitu:

Tabel 1 Status Padang Lamun

\begin{tabular}{clc}
\hline \multicolumn{2}{c}{ KONDISI } & $\begin{array}{c}\text { PENUTUPAN } \\
(\%)\end{array}$ \\
\hline BAIK & KAYA/SEHAT & $\geq 60$ \\
\hline RUSAK & KURANG & $30-59,9$ \\
& KAYA/KURANG & \\
& SEHAT & \\
\cline { 2 - 3 } & MISKIN & $\leq 29,9$ \\
\hline
\end{tabular}

3. Metode loss on ignition (LOI) ini pada prinsipnya adalah menghilangkan bahan organik melalui proses

\section{Volume 8 Nomor 2 Tahun 2020}

pembakaran di dalam tanur/tungku (furnace). Untuk menghitung kandungan bahan organik menggunakan persamaan 3

(Heiri, et al. 2001; Santisteban, et al. 2004; Fourqurean, et al. 2014).

$\%$ LOI bahan organik $=((D-E) /(D-$ C)) $x 10$

Keterangan :

C = berat cawan porselen kosong

$\mathrm{D}$ = berat awal cawan porselen + sampel

$\mathrm{E}$ = berat akhir cawan porselen + sampel setelah pemijaran

Sesudah diketahui nilai kandungan bahan organik, kemudian menghitung persamaan kandungan karbon dengan rumus pada persamaan 5 (Helrich, 1990)

Kandungan karbon $=\frac{\text { bahan organik }}{1,724}$.

dimana 1,724 adalah konstanta nilai bahan organik.

\section{HASIL DAN PEMBAHASAN}

\section{Keanekaragaman}

Hasil analisis keanekaragaman lamun dari keseluruhan stasiun dengan menggunakan indeks Shannon-Wienner disajikan pada gambar 3 . 


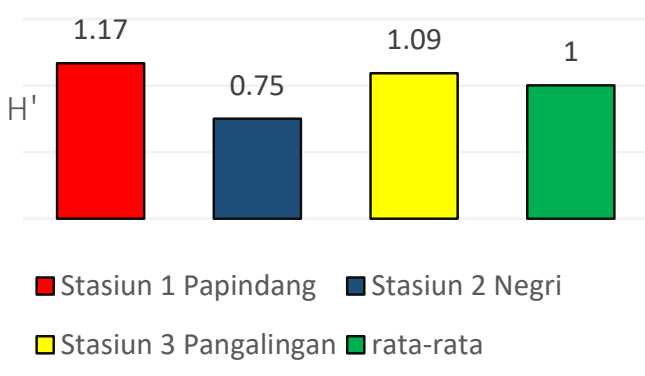

Gambar 3 Indeks keanekaragaman

Dari hasil analisis indeks keanekaragaman pada gambar 3 didapatkan nilai indeks keanekaragaman sebesar H' 1 yang tergolong sedang. Nilai indeks keanekaragaman yang diperoleh dari penelitian ini sama dengan nilai indeks keanekaragaman yang didapat oleh (Maabuat et, al. 2012) yaitu sebesar H' 1 yang tergolong sedang pada pantai Molas Kecamatan Bunaken.

Diketahui bahwa kesamaan hasil indeks keanekaragaman pada perairan pulau manado tua dan molas bisa disebabkan karena adanya kesamaan sebaran jenis yang didapat, sebaran jenis yang didapat pada keseluruhan stasiun pada perairan pulau manado tua yaitu dari family Hydrocharitaceae; Enhalus acoraides, Thalassia hemprichii, dan Halopila ovalis. dan family Cymodoceaceae yaitu ; Syringodium isoetifolium, dan Haludole pinifolia. Dari semua stasiun hanya stasiun papindangan yang memiliki kelima jenis lamun tersebut, sedangkan stasiun negri dan pangalingan hanya memiliki tiga jenis dari kelima jenis yang didapat pada stasiun papindang,
Jenis-jenis lamun yang didapat dilihat pada gambar 4

Gambar 4. Jenis-jenis lamun

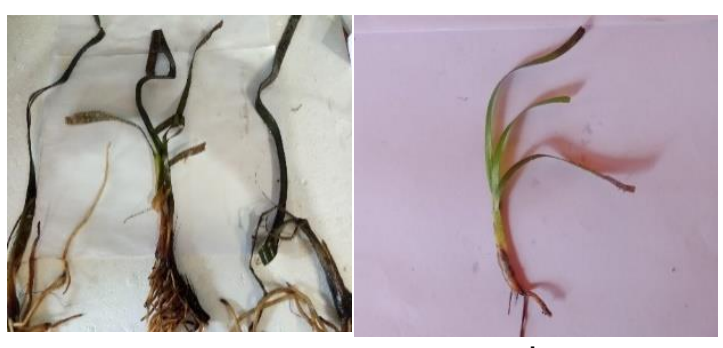

a b
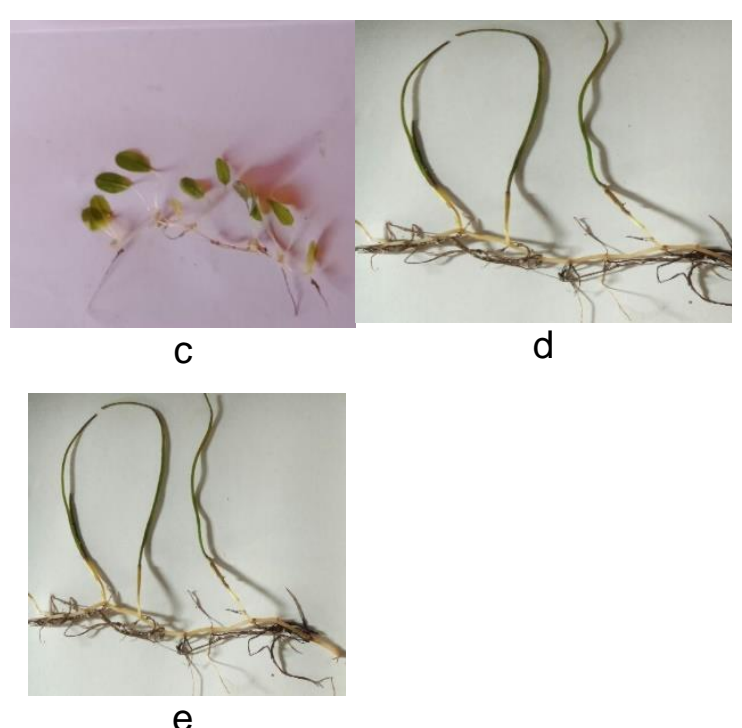

e

(a. E acoraides, b. Themprichii c. Hovalis, d. $S$ isoetifolium, e. H pinifolia)

\section{Presentase Penutupan Lamun}

Hasil presentase penutupan lamun menentukan kondisi padang lamun dimana semakin tinggi nilai presentase penutupan lamun maka kondisi padang lamun juga semakin baik, hasil presentase penutupan lamun terlihat pada gambar 5 


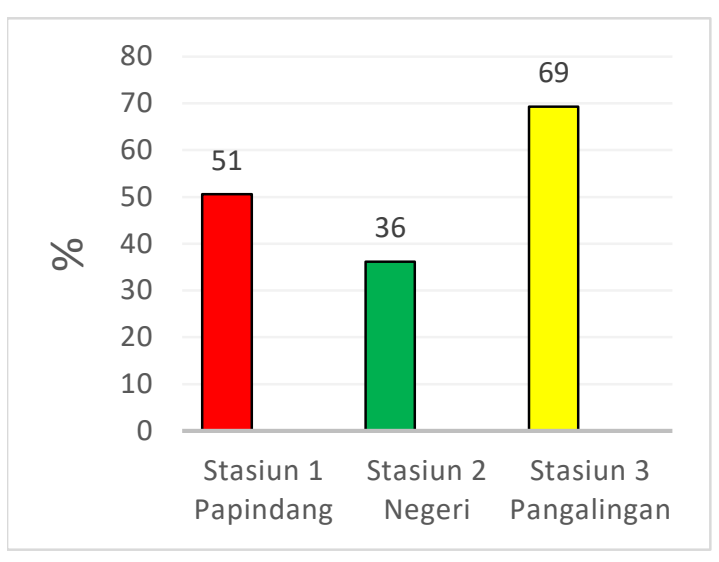

Gambar 5. Hasil presentase tutupan lamun setiap stasiun

Dari hasil presentase pada gambar 5 terlihat presentase tutupan lamun terbesar pada stasiun pangalingan yaitu $69 \%$ dan pada stasiun papindang memiliki presentase 51\%, sedangankan hasil presentase penutupan paling terendah terdapat pada stasiun negri 36\%. Menurut Gacia, et al. (2002) perubahan kondisi lingkungan dapat mempengaruhi penutupan dan pertumbuhna lamun menjadi naik atau turun, sehingga luasan padang lamun di suatu lokasi bisa berubah setiap saat. Hal ini diperkuat oleh (Waycott, et al. 2009) penyebab utama rusaknya padang lamun adalah penurunan kecerahan air, baik karena peningkatan kekeruhan air maupun kenaikan masukan zat hara ke perairan.

Berdasarkan panduan dari Keputusan Mentri Lingkungan Hidup no 200 tahun 2004 tentang Kriteria Baku Kerusakan dan Pedoman Penentuan Status Padang Lamun, maka status padang lamun dari setiap stasiun penelitian dapat dikategorikn sebagai.
Tabel 2. Status padang lamun Sesuai Kepmen KLH 200 Thn 2004

\begin{tabular}{ccc}
\hline Stasiun & $\begin{array}{c}\text { Tutupan } \\
\%\end{array}$ & Kondisi \\
\hline Papindang & 51 & $\begin{array}{l}\text { Kurang kaya/ } \\
\text { kurang sehat }\end{array}$ \\
\hline Negri & 36 & $\begin{array}{l}\text { Kurang kaya/ } \\
\text { kurang sehat }\end{array}$ \\
\hline Pangalingan & 69 & Kaya/ Sehat \\
\hline
\end{tabular}

\section{Kandungan Bahan Organik}

Menurut Riniatsih (2015) kandungan bahan organik pada lamun juga dapat dipengaruhi oleh penutupan lamun dimana jika penutupan lamun dan morfologi semakin tinggi maka akan semakin banyak kandungan bahan organik yang terikat pada bagian lamun.

Perolehan nilai persentase kandungan bahan organik didapatkan dari hasil pengabuan sampel, nilai rata-rata kandungan bahan organik dapat dilihat pada gambar 6 .

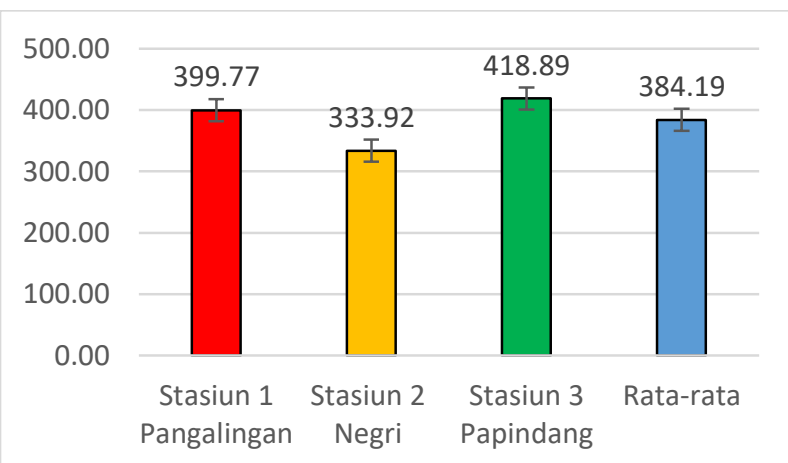

Gambar 6. Grafik nilai kandungan organik

Setelah dilakukan perhitungan dengan menggunakan persamaan (4) kandungan bahan organik. Hasil nilai persentase kandungan bahan organik paling rendah pada stasiun dua desa Negri yaitu 333,92\%, 


\section{Jurnal Pesisir dan Laut Tropis}

sedangkan pada stasiun satu desa Pangalingan memilki presentase 399,77\%, dan pada stasiun tiga Papindang memiliki presentase kandungan bahan organik terbesar $418,88 \%$. Jika di rata-ratakan totol kandungan bahan organik pada semua stasiun adalah $384,19 \%$.

\section{Kandungan karbon}

Kandungan karbon pada lamun menggambarkan seberapa besar lamun tersebut dapat mengikat $\mathrm{CO}_{2}$ dari udara (Carruthers, et al. 2007).

Berdasarkan perhitungan kandungan karbon dengan menggunakan

Nilai rata-rata kandungan karbon total pada keseluruhan stasiun yaitu sebesar $222,85 \mathrm{gC}$. Jenis substrat yang terdapat pada lokasi penelitian adalah pasir bercampur karang dimana jenis substrat yang umum ditinggali lamun.

Menurut Yunitha (2015) bahwa penyerapan karbon sangat dipengaruhi oleh besaran butiran substrat, karena semakin besar butiran substrat akan menurunkan kemampuan substrat tersebut mengikat karbon, hal ini sesuai pernyataan yang di sampaikan oleh (Christon, et al. 2012) bahwa besarnya kandungan karbon pada lamun terdapat pada substrat yang lebih kecil (halus) disebabkan oleh efek positif terhadap sisitem penyerapan nutien, sebaliknya substrar yang lebih kasar akan menurunkan penyerapan nutrien pada lamun sehingga
Volume 8 Nomor 2 Tahun 2020

metode (LOI) sebaran nilai rata-rata kandungan karbon dapat dilihat pada gambar 7.

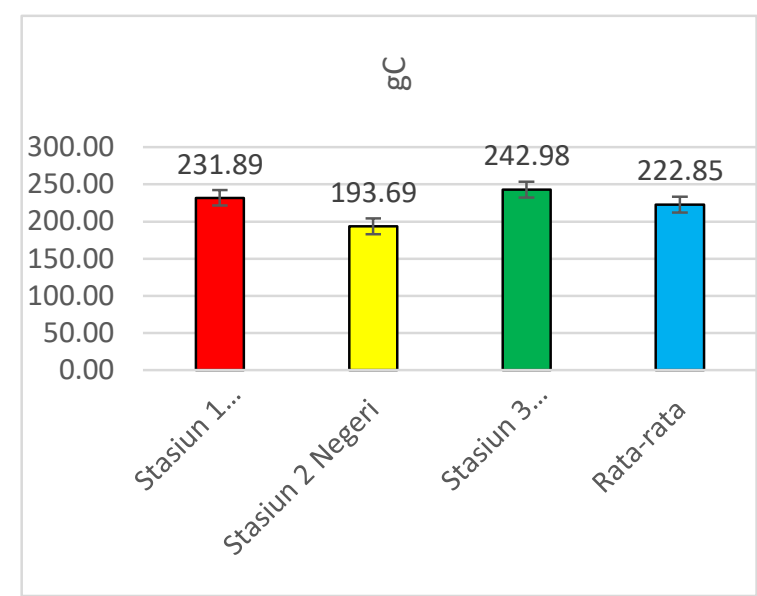

Gambar 7. Kandungan karbon

mempengaruhi besar kecilnya simpanan karbon yang terserap oleh lamun.

\section{KESIMPULAN DAN SARAN}

\section{Kesimpulan}

Didapat indeks keanekaragaman keseluruhan pada perairan Pulau Manado Tua sedang dengan nilai H'1 dengan lima jenis lamun yang didapat terdiri dari dua family Hydrocharitaceae dan Cymodceaceae. Tiga jenis dari family Hydrocharitaceae yaitu ; Enhalus acoraides, Thalassia hemprichii, dan Halopila ovalis, dua jenis dari Cymodoceaceae yaitu ; Syringodium isoetifolium, dan Haludole pinifolia, dengan presentase penutupan dan status kondisi pada stasiun negri 36\% kurang kaya/kurang sehat, stasiun pangalingan 
Jurnal Pesisir dan Laut Tropis

69\% kaya/sehat dan stasiun papindang $51 \%$ kurang kaya/kurang sehat.

Kandungan kabon yang didapat pada padang lamun di Perairan Pulau Manado Tua adalah 222,85 gC .

\section{Saran}

Berdasarkan hasil yang diperoleh selama penelitian, saran yang dapat diajukan adalah adanya peneletian berkelanjutan mengenai simpanan karbon, indeks keanekaragaman jenis, dan penutupan padang lamun pada perairan pulau Manado Tua sehingga ada perkembanggan informasi yang terjadi secara terus menerus.

\section{DAFTAR PUSTAKA}

Carruthers, T.J.B., W.C. Dennison, G.A. Kendrick, M. Waycott, D.I. Walker, M.L. Cambridge., 2007 Seagrasses of south-west Australia: A conceptual synthesis of the world's most diverse and extensive seagrass meadows. Journal of Experimental Marine Biology and Ecology 350. 2145

Christon, C., Djunaedi, O. S, dan Purba , N. P. 2012. Pengaruh Tinggi Pasang Surut Terhadap Pertumbuhan dan Biomassa Daun Lamun

Fachrul., 2007. Metode sampling Bioekologi. Penerbit Bumi Aksara

Fourqurean, J.W., B,Jhonson., J.B. Kauffman., H. Kennedy., I. Emmer.

\section{Volume 8 Nomor 2 Tahun 2020}

J.Howard., E. Pidgeon ., O.Serrano. 2014. Conceptualizing the project and Developing a Field Measurement Plan. Dalam Howard, J., S. Hoyt., K Isensee., E. Pidgeon., M. Telszewski. Coastal Blue Carbon: Methods for Assessing Carbon Stock and Emissions factor in Mangrove, Tidal Salt Marsh and Seagrass Meadow. The Blue Carbon Initiative. 39 - 107 hal.

Fourqurean, J. W., Duarte, C. M., Kennedy, H., Marbà, N., Holmer, M., Mateo, M. A. Serrano, O. (2012). Seagrass ecosystems as a globally significant carbon stock. Nature Geoscience, 5(7), 505-509.

Gacia, E; Duarte, C.M and Middelburg, J.J (2002) Carbon and nutrient deposition in a Mediterranean seagrass (Posidonia oceanica) meadow.Limnol. Oceanogr 47(1) 23 $-32$

Helrich K. 1990. Method of Analysis of the Association of Official Analytical Chemists, Fifteenth Edition. Virginia: Wilson Boulevard. 771 hal.

Heiri, O., F. Lotter., and Gerry Lemcke. 2001 Loss on ignition as a method for estimating organic and carbonate content in sediments: reproducibility and comparability of results, Journal of Paleolimnology 25: 101-110, 2001 Hutomo, M. And Nontji, A.,2014. Panduan Monitoring Padang Lamun. COREMAP CTI Lembaga IImu 
Pengetahuan Indonesia, $37 \mathrm{p}$.

Kawaroe., M. 2009. Perpektif Lamun

Sebagai Blue Carbon Sink di Laut.

Dalam: Lokakarya Nasional I

Pengelolaan Ekosistem Lamun

Tanggal 18 November 2009.

Keputusan Menteri Negara Lingkungan

Hidup Nomor 200 tahun 2004 tentang Kriteria Baku dan Pedoman Penentuan Status Padang Lamun.

Kennedy, H and M. Bjork. 2009.

Seagrasses Meadows, In: Laffoley,

D. d'A dan Grimsditch, G. (eds). 2009. The Management of Natural Coastal Carbon Sinks. IUCN. Gland.

Nurul, E.H.S, Hermawan, E.K, Bayu, P, Happy Supriyadi, I. Yulia Iswari M, Anggraini, K. Rahmawati, S, Suyarso 2018vero2. Status padang lamun Indonesia COREMAP CTI Lembaga IImu Pengetahuan Indonesia. 50hal

Udhi, E.H, Nurul D.M.S, Supriyadi H.Y, Suyarso, Yulia Iswari M, Anggraini, K. Rahmat. 2017 Status padang lamun Indonesia COREMAP CTI Lembaga Ilmu Pengetahuan Indonesia. 26hal

Maabuat, U.P. Sampekalo, J, H.E.I. Sambala. 2012 Keanekaragaman lamun dipesisie pantai molas, Kecamatan Bunsken Kota Manado. Ejurnal.UNSRAT.ac.id. 25hal

McKenzie. Campbell, S.J \& Roder, C.A (2003). Seagrasswatch: Manual for mapping \& monitring seagrass resources by community (citizen) volunteers 2 sd edition. The state of
Queensland, Department of Primary Industries, CRC Reef. Queensland. pp 104

McLeod, E., Chmura, G. L., Bouillon, S., Salm, R., Björk, M., Duarte,C.M.,Lovelock,C.E.,Schlesin ger,W.H.,andSilliman,B.R.:

blueprint for blue carbon: 2011, toward an improved understanding of the role of vegetated coastal habitats in sequestering $\mathrm{CO} 2$, Front. Ecol. Environ., 9, 552-560.

Nellemann, C., E. Corcorn, C.M. Duarte, L. Valdés, C. DeYoung, L. Fonseca \& G. Grimsditch. 2009. Blue carbon. A rapid response assessment. United Nations Environment Programme. Norway. 78 pp.

Riniatsih I. 2015. Distribusi Muatan Padatan Tersuspensi (MPT) di Padang Lamun di Perairan Teluk Awur dan Pantai Prawean Jepara. Jurnal Kelautan Tropis. Volume 18, No. 3: 121-126

Santisteban, J. I. et al. (2004) 'Loss on ignition: a qualitative or quantitative method for organic matter and carbonate mineral content in sediments?'Journal of Paleolimnology,32(3), pp. 287-299.

Wagey B. T., 2018. Studies on seagrasses of North Sulawesi, Indonesia and adjacent waters: a critical review. eJournal Budidaya Perairan 6(2):1-6.

Wagey B.T, 2013. Hlamun (Segrass).

Unsrat Pres, 122 hal.

Waycott, M., C.M. Duarte, T.J.B. 
Carruthers, S. Olyamik, A. Calladine, J.W. Fourqurean, K.L.Heck Jr., A.R.Hughes, G.A. Kendrick, W.J. Kenworthy, F.T.Short and S.L. Williams. 2009. Accelerating loss of seagrass across the globe threaten coastal ecosystems. PNAS, 106(30), pp. $12377-12381$
Yunitha, Alpinina. 2015. Kandungan COrganik pada Lamun Berdasarkan Habitat dan Jenis Lamun di Pesisir Desa Bahoi Kabupaten Minahasa Utara, Sulawesi Utara. Thesis. Sekolah Pascasarjana, Institut Pertanian Bogor, Bogor. 